\title{
Effect of Tool Coating and Cutting Parameters on Surface Roughness and Burr Formation during Micromilling of Inconel 718
}

\author{
Atif Muhammad $^{1}{ }^{\mathbb{D}}$, Munish Kumar Gupta ${ }^{2,3} 3^{\mathbb{D}}$, Tadeusz Mikołajczyk ${ }^{4} \mathbb{D}$, Danil Yurievich Pimenov ${ }^{3} \mathbb{D}$ \\ and Khaled Giasin $5, *$ (D)
}

Citation: Muhammad, A.; Kumar Gupta, M.; Mikołajczyk, T.; Pimenov, D.Y.; Giasin, K. Effect of Tool Coating and Cutting Parameters on Surface Roughness and Burr Formation during Micromilling of Inconel 718. Metals 2021, 11, 167. https://doi.org/ $10.3390 /$ met11010167

Received: 11 December 2020

Accepted: 12 January 2021

Published: 18 January 2021

Publisher's Note: MDPI stays neutral with regard to jurisdictional claims in published maps and institutional affiliations.

Copyright: (c) 2021 by the authors. Licensee MDPI, Basel, Switzerland. This article is an open access article distributed under the terms and conditions of the Creative Commons Attribution (CC BY) license (https:// creativecommons.org/licenses/by/ $4.0 /)$.
1 Beijing Institute of Technology, 5 Zhongguancun St, Haidian District, Beijing 100811, China; matif@bit.edu.cn

2 Key Laboratory of High Efficiency and Clean Mechanical Manufacture, Ministry of Education, School of Mechanical Engineering, Shandong University, Jinan 250100, China; munishgupta@sdu.edu.cn

3 Department of Automated Mechanical Engineering, South Ural State University, Lenin Prosp. 76, 454080 Chelyabinsk, Russia; danil_u@rambler.ru

4 Department of Production Engineering, UTP University of Science and Technology Bydgoszcz, Al. prof. S. Kaliskiego 7, 85-796 Bydgoszcz, Poland; tami@utp.edu.pl

5 School of Mechanical and Design Engineering, University of Portsmouth, Portsmouth PO1 3DJ, UK

* Correspondence: Khaled.giasin@port.ac.uk

\begin{abstract}
Surface roughness and burr formation are among the most important surface quality metrics which determine the quality of the fabricated parts. High precision machined microparts with complex features require micromachining process to achieve the desired yet stringent surface finish and dimensional accuracy. In this research, the effect of cutting speed $(\mathrm{m} / \mathrm{min})$, feed rate ( $\mu \mathrm{m} /$ tooth), depth of cut $(\mu \mathrm{m})$ and three types of tool coating (AlTiN, nACo and TiSiN) were analyzed to study their effect on surface roughness and burr formation during the micromachining of Inconel 718. The analysis was carried out using an optical profilometer, scanning electron microscope and statistical technique. Machining tests were performed at low speed with a feed rate ( $\mu \mathrm{m} / \mathrm{tooth})$ below the cutting-edge radius for $10 \mathrm{~mm}$ cutting length using a carbide tool of $0.5 \mathrm{~mm}$ diameter on a CNC milling machine. From this research, it was determined that the depth of cut was the main factor affecting burr formation, while cutting velocity was the main factor affecting the surface roughness. In addition, cutting tool coating did not significantly affect either surface roughness or burr formation due to the difference in coefficient of friction. The types of burr formed during micromilling of Inconel 718 were mainly influenced by the depth of cut and feed rate $(\mu \mathrm{m} /$ tooth) and were not affected by the cutting velocity. It was also concluded that the results for the surface finish at low-speed machining are comparable to that of transition and high-speed machining, while the burr width found during confirmation experiments at low-speed machining was also within an acceptable range.
\end{abstract}

Keywords: Inconel 718; micromachining; micromilling; surface roughness; burr formation; tool coatings

\section{Introduction}

There is an increased demand for the miniaturization of components in industrial products, which has many functions and requires acceptable dimensional accuracy [1]. Micromachining is a process of producing miniature parts and components in mass production [2]. Several definitions exist on what is meant by micromachining. It can be defined based on size metrics as a process which can produce small and intricate three-dimensional features ranging from 1 to $999 \mu \mathrm{m}$ according to size aspects as a material removal process in which material is being removed in microlevels [3,4]. In recent years, demand for microparts and components has increased in different industrial sectors. Examples of such parts include, but are not limited to, the following: connectors, diagnostic devices, microreactors, medical implants, microengines, switches, micropumps drug delivery systems, and printing heads [5-9]. Fabrication of small parts requires more reliable, 
precise, and repeatable methods, with a precise tooling system. Many scholars have investigated other manufacturing methods for the manufacturing of microcomponents, such as laser manufacturing, photolithography methods, and ultrasonic and ion beam machining [10-15]. Material removal rate is among the main challenges in mechanical micromachining [16]. This is because well-established cutting mechanisms and underlying physical "size effect" phenomena observed in the macromachining domain are different from that in the micromachining domain $[17,18]$. Micromilling of Inconel alloys is among the most investigated materials in the open literature due to its large base of applications in many industries. This is thanks to the ability of micromilling to produce a required design on nickel-based microcomponents [19-22].

Inconel belongs to the group of austenitic nickel-chromium-based superalloys of which Inconel 718 is among the most used in the oil and gas industries. Inconel 718 is a nickel-chromium alloy that has high strength and resistance to corrosion at a very high temperature [23]. Inconel 718 also has excellent mechanical properties at a high temperature which can be used to fulfill the requirements in different areas such as aviation, automotive and biomedical applications [24-26]. Nickel alloy is hard to cut material and has poor machinability due to its low thermal conductivity which promotes built-up edge when machined, work hardening and high affinity towards tool materials. Due to the low thermal conductivity of Inconel 718, the temperature at the cutting zone increases significantly during machining which decreases the tool life $[27,28]$. Previous studies on machining Nickel alloy showed that temperature at the tool-workpiece interface increases rapidly with the increase in cutting speed more than when the feed rate is increased [29]. From the literature review, it was also found that high cutting speed is more effective during micromachining processes [30-32]. The machinability of Inconel alloys has been the focus of many researchers in the past in the macro- and micromachining domains. Table 1 shows a summary of some of the past studies on micromachining of Inconel 718 alloy.

Different assistive methods are used to increase the machining performance during the machining of Inconel 718 such as the use of different coatings, different types of coolants, changing the machining parameters and preheating the workpiece using laser-assisted machining to soften the material and make it easier to be machined [32,43-46]. The results showed that the specific cutting energy and surface roughness improved in comparison with conventional machining. Irfan et al. [47] investigated the effect of coating on surface roughness and tool wear during high speed $(48 \mathrm{~m} / \mathrm{min})$ micromachining of Inconel 718 . Diamond-Like Coatings (DLC) and TiAIN +WC/C coatings show good performance against tool wear and Built-Up Edge (BUE) formation. Minimum surface roughness was achieved by the DLC coated tool, followed by the AlTiN- and TiAlN + WC/C coated tools. High tool wear was observed at small depths of cut and low feed rates [45,47]. Xiaohong Lu et al. [48] found that the surface roughness is influenced by the cutting parameters, tool condition, machining vibrations and BUE formation. Surface roughness was found to decrease at first but started increasing with the increase in the cutting length [48]. K. Aslantas et al. [49] investigated the effect of tool coating on tool wear and cutting force and its effects on machining quality during micromilling of Ti6Al4V alloy. It was observed that tool wear is the main cause for the increase in cutting force, which in turn reduces the machining quality. T. Ozel et al. [50] also compared the performance of a cBN coated tool with an uncoated tool during micromilling of Ti6Al4V from which it was concluded that cBN coated tool performs better in terms of tool wear and machining quality compares to that of an uncoated tool. A. Aramcharoen et al. [51] investigated the effect of different tool coatings on the tool wear during micromilling of hardened tool steel. Among different tool coatings, the TiN was seen to be more wear resistance in terms of flank wear and edge chipping, while TiAlN led to an increase in burr formation compared to that of the uncoated tool, which was not investigated further to find the cause for the increase in burr formation. 
Table 1. Summary of past studies on micromachining of Inconel 718 alloys.

\begin{tabular}{|c|c|c|c|c|}
\hline Workpiece Details & Cutting Tool Details & Cutting Parameters & Studied Parameters & Reference \\
\hline- & $\begin{array}{l}\text { Ultrafine particle coated } \\
\text { cemented carbide end milling } \\
\text { tool with two flutes }\end{array}$ & $\begin{array}{l}\text { FPT }(\mu \mathrm{m} / \mathrm{z}) 0.81 .21 .6 \\
\text { DOC }(\mathrm{mm}) 0.10 .250 .4 \\
\text { kRPM } 405060\end{array}$ & SR, MRR & [33] \\
\hline Grain size $24 \mu \mathrm{m}$ & $\begin{array}{l}\text { Two-fluted microend milling } \\
\text { tools } \varnothing=0.35 \mathrm{~mm}\end{array}$ & $\begin{array}{l}\text { FPT }(\mu \mathrm{m} / \mathrm{z}) 0.5 \text { to } 10 \\
\text { DOC }(\mu \mathrm{m}) 75100\end{array}$ & MUCT & {$[34]$} \\
\hline $50 \mathrm{~mm} \times 50 \mathrm{~mm} \times 102 \mathrm{~mm}$ & $\mathrm{CER}=10 \mu \mathrm{m}, \varnothing=1 \mathrm{~mm}$ & $\begin{array}{l}\text { FPT }(\mu \mathrm{m} / \mathrm{z}) 0.56 \text { to } 1.24 \\
\text { DOC }(\mathrm{mm}) 13.16 \text { to } 46.82 \\
\text { RPM } 43,200 \text { to } 76,800\end{array}$ & Cutting temperature & [35] \\
\hline- & $\begin{array}{l}\text { Cemented carbide with TiAlN } \\
\text { coated tool, } \\
\varnothing=1 \mathrm{~mm}, \mathrm{CER}(\mu \mathrm{m})=024\end{array}$ & $\begin{array}{c}\text { FPT }(\mu \mathrm{m} / \mathrm{z}) 0.90 .70 .1 \\
\text { DOC }(\mathrm{mm}) 3040 \\
\text { RPM 40,000,60,000,80,000 } \\
\text { NCR }(\mu \mathrm{m}) 251015\end{array}$ & $\begin{array}{l}\text { FE model, NCR, CER and } \\
\text { Cutting parameters on } \mathrm{CF}\end{array}$ & [36] \\
\hline $\begin{array}{c}\text { Inconel } 718 \text { sheet } \\
30 \mathrm{~mm} \times 10 \mathrm{~mm} \times 3 \mathrm{~mm} \\
\text { machining length }=10 \mathrm{~mm}\end{array}$ & $\begin{array}{l}\text { AlTiN coated two-flute WC micro } \\
\text { endmill cutter. } \\
\varnothing=0.5 \mathrm{~mm} \text { CER }=3 \mu \mathrm{m}\end{array}$ & $\begin{array}{c}\text { FPT }(\mu \mathrm{m} / \mathrm{z}) 0.1 \text { to } 6 \\
\text { DOC }(\mathrm{mm}) 0.1 \\
\text { RPM } 5000 \text { Sunflower-based } \\
\text { vegetable oil } 50 \mathrm{~mL} / \mathrm{h}\end{array}$ & $\begin{array}{l}\text { SR and BF for dry and } \\
\text { sunflower oil-based. } \\
\text { MQL-assisted } \\
\text { micro-end milling }\end{array}$ & [37] \\
\hline Cutting length $=430 \mathrm{~mm}$ & $\begin{array}{l}\text { Fine grain carbide tool } \varnothing=1 \mathrm{~mm} \text {. } \\
\text { Number of flutes }=234, \text { Helix } \\
\text { angles }\left(25^{\circ}, 35^{\circ}, 45^{\circ}\right) \text { and axial } \\
\text { rake angles }\left(-5^{\circ}, 0^{\circ}, 5^{\circ}\right)\end{array}$ & $\begin{array}{l}\text { FPT }(\mu \mathrm{m} / z) 3 \\
\text { DOC }(\mathrm{mm}) 0.1 \\
\text { RPM } 10,000\end{array}$ & $\begin{array}{c}\text { Tool geometry on SR, CF, } \\
\text { and BF }\end{array}$ & [38] \\
\hline $\begin{array}{l}15 \mathrm{~mm} \times 10 \mathrm{~mm} \times 15 \mathrm{~mm} \\
\text { Cutting length }=15 \mathrm{~mm}\end{array}$ & $\begin{array}{l}\text { Ultra-refined cemented carbide } \\
\text { microend mill coated with AlTiN, } \\
\qquad \varnothing=0.4 \mathrm{~mm}, 2 \text { flutes }\end{array}$ & $\begin{array}{c}\text { FPT }(\mu \mathrm{m} / \mathrm{z}) 3 \\
\text { DOC }(\mathrm{mm}) 40 \\
\text { RPM } 20,000, \text { CFFR } 40.7 \mathrm{~mL} / \mathrm{hr}\end{array}$ & Cutting fluid on SR and BF & [39] \\
\hline Cutting length $=8 \mathrm{~mm}$ & $\begin{array}{l}\text { Ultrafine particle coated (TiAlN) } \\
\text { cemented carbide end milling } \\
\text { tool, } 2 \text { flutes }\end{array}$ & $\begin{array}{c}\text { FPT }(\mu \mathrm{m} / \mathrm{z}) 0.10 .30 .5 \\
\text { DOC }(\mu \mathrm{m}) 203040 \\
\text { RPM } 40,000,60,000,80,000\end{array}$ & $\begin{array}{c}\text { Cutting parameters on SR } \\
\text { and MRR }\end{array}$ & [40] \\
\hline $\begin{array}{l}20 \mathrm{~mm} \times 10 \mathrm{~mm} \times 15 \mathrm{~mm} \\
\text { Cutting length }=15 \mathrm{~mm}\end{array}$ & $\begin{array}{c}\text { Flat end mill, } 2 \\
\text { flutes, } \varnothing=0.6 \mathrm{~mm} \text { tool hardness } \\
3000 \text { to } 3500 \mathrm{HV}\end{array}$ & $\begin{array}{c}\text { Overhang length }(\mathrm{mm}) 101520 \\
\text { RPM 20,000 } \\
\text { FPT }(\mu \mathrm{m} / \mathrm{z}) 12345 \\
\text { DOC }(\mu \mathrm{m}) 100\end{array}$ & $\begin{array}{c}\text { Feed and overhang length } \\
\text { on the tool wear, } \mathrm{CF}, \\
\text { and } \mathrm{BF}\end{array}$ & [41] \\
\hline Cutting length $=15 \mathrm{~mm}$ & $\begin{array}{c}\text { AlTiN coated tungsten } \\
\text { carbide endmill, } \\
\varnothing=0.5 \mathrm{~mm}, \mathrm{CER}=2.97 \mu \mathrm{m}\end{array}$ & $\begin{array}{l}\text { FPT }(\mu \mathrm{m} / \mathrm{z}) 0.56 \\
\text { DOC }(\mu \mathrm{m}) 50 \\
\text { RPM } 5000\end{array}$ & Tool wear, SR, BF, CF & {$[42]$} \\
\hline
\end{tabular}

SR: Surface roughness; BUE: Built-Up Edge, MR: Material Removal Rate, MUCT: Minimum Uncut Chip Thickness, CER: Cutting-Edge Radius, NCR: Nose Corner Radius, BR: Burr Formation, MQL: Minimum Quantity Lubrication, CF: Chip Formation, FTP: Feed Per Tooth.

Chip formation is mostly nonlinear in nature; therefore, to accurately predict the cutting forces, it is important to understand the mechanisms of microchip formation. Different materials have different minimum chip thickness values below which proper chips are not formed. Therefore, for the formation of a chip, the feed rate ( $\mu \mathrm{m} /$ tooth) must be equal to or greater than the minimum chip thickness [52]. The variation in chip thickness $h(\varnothing)$ in a milling process can be estimated as $h(\varnothing)=\mathrm{c} \sin (\varnothing)$, where $\varnothing$ denotes the angle of immersion and $c$ denotes the feed rate ( $\mu \mathrm{m} /$ tooth) [53]. However, this estimation cannot be applied to micromilling processes to estimate the variation in chip thickness. This is because of the small cutting edge of the tool, low feed rate and the small depth of cut which cause a very large negative rake angle. In addition, ploughing phenomena are common in micromachining, which tends to increase the surface roughness and elastic recovery of the workpiece [54,55].

Abd Rahman et al. [32] concluded that the depth of cut and the feed rate were the dominant factors for tool vibration, whereas cutting speed had a substantial impact on surface roughness. Abd Rahman et al. [30] concluded that economical cooling techniques such as Minimum Quantity Lubrication (MQL) show more consistency and stability during the micromachining process than dry machining for Inconel 718. During a dry cutting process, the tool wear is high due to the increase in the contact area between the tool and workpiece, which results in higher temperature, increase in diffusion and adhesion compared to a wet machining process [56]. Muhammad et al. [57] found that the tool life 
in a wet machining process is greater compared to a dry machining process due to the heat removal process. Liu et al. [58] reported that during a dry machining process of Inconel, the specific energy of the machine tool increased slightly as the tool wear increased.

Xiaohong Lu et al. [59] found that with the increase in the overhanging length of the micromilling cutter and depth of cut, the fluctuation in the cutting forces increases. The cutting forces first increase and then decrease with an increase in cutting speed and feed rate. The minimum chip thickness found for Inconel 718 is 0.35 of the rounded cutting-edge radii. Kovvuri [60] found that there is a minimum chip thickness below which the chip cannot be formed. Several studies investigated burr formation in micromilling processes. Burr formation is among the biggest problems in conventional machining processes. It occurs in both the macromachining process and the micromachining process. In the macromachining process, the removal of the burrs is easy and has different procedures for removal due to their relatively large size. In micromachining, the removal of the burrs is difficult due to its small size and high accuracy required to avoid damaging the microfeatures of the machined part during the deburring process [61,62]. Extra measures can be taken for less burr formation during the micromilling process through process control such as cutting process characteristics and cutting conditions [63]. Dornfeld et al. [64] investigated the formation of burrs in micromilling. The burr formed during conventional machining was bigger considering the feed rate ( $\mu \mathrm{m} /$ tooth) to burr size ratio which is due to the low cutting speed in conventional machining. The material deforms more at low speed and breaks at high speed; therefore, the burr formation is greater. Large tool edge radius to feed rate ( $\mu \mathrm{m} /$ tooth) ratio produces more burr during rubbing and compression instead of cutting. In dry cutting conditions, there is an increase in cutting temperature which causes the buildup of edges on the machine surface that decreases the surface quality. Residual tensile stresses of the workpiece can be reduced using lubricants; however, the contribution of lubricants becomes less effective at very high cutting speeds [56].

The development of tool wear and its impact on machining quality have been the scope in many past studies on micromilling. During micromachining processes, a small depth of cut causes a considerable increase in friction between the workpiece and the tool, which results in temperature rise and tool wear. Because of this, there is an increase in the tool cutting-edge radius, which lowers the quality of the component and increases the tool wear rate $[65,66]$. Tansel et al. [67] developed a method to estimate tool wear using wear data and cutting forces for micromachining of steel and aluminum; machining steel was found to cause faster tool wear rates than aluminum. Weule et al. [68] observed that tool wear is highly influenced by the machined material. Different types of tool coating can also be used to increase the tool life during micromachining of Inconel 718 [31,47,69]. Tool coating with low friction of coefficient can be used to reduce the tool wear mechanism and improve surface quality $[69,70]$. The cryogenic tooling process can be used to decrease the -cutting-edge temperature during the machining process to increase the tool life [31].

Different researchers have focused on different aspects of input parameters to increase the machine surface quality during micromachining processes. Aldo Attanasio et al. [71] focused on the effect of material microstructure on final machining quality (burr formation), cutting forces and tool wear. Zhanwen Sun and Suet To [72] focused on input cutting parameters such as spindle speed, feed rate, depth of cut and tool wear in order to increase the machining quality by analyzing surface uniformity. Jan C. Aurich et al. [73] focused on the tilt angle of the spindle speed to increase the machining quality during the micromachining process and concluded that the tilt angle of the spindle speed decreased both surface roughness and burr formation. Pavel Filippov et al. [74] investigated the effect of tool geometry on surface roughness and strain hardening during micromilling of aluminum alloy. It was concluded that the tool with a higher cutting-edge radius ( $r$ ) produced a high surface roughness and large depth of strain hardening zone, whereas smaller $r$ produced a low surface roughness and low depth of strain hardening zone. Menghua Zhou et al. [75] investigated the effect of cutting parameters such as spindle speed, feed rate, axial depth of cut and extended length of tool on the burr formation and cutting force. It was con- 
cluded that the cutting parameters had a linear relation with both the cutting force and burr formation.

Alexander Meijer et al. [76] focused on simulation in order to decrease the surface roughness considering the $r$, secondary cutting-edge and feed rate as input parameters. It was concluded that these parameters had a strong influence on the surface roughness of the micromachine surface. Jinxuan Bai et al. [77] focused on the influencing parameters during the ductile mode micromachining in which it was concluded that vibration thrust force causes a brittle fracture and a smooth ductile cutting is achieved by smooth thrust force. Ugur Koklu and Gültekin Basmaci [78] focused on the effect of different tool path strategies with different cooling conditions on cutting force during micromilling. It was concluded that the contour tool path decreased the cutting force and increased the surface quality compared to the hatch tool path where using the flood cooling system also helped in increasing surface quality by increasing the chip removal and decreasing the cutting temperature.

From the literature, it can be seen that many researchers used different types of tool coatings in order to increase the tool life and compatibility with different materials during micromilling processes, but a different tool coating was not investigated in order to observe its effect on machining quality by neglecting tool wear. Most of the past studies were carried out using high cutting speeds because of less tool vibration and low burr formation at high cutting speed, while only a handful of studies investigated the quality of micromachined parts at low cutting speeds $[45,48,59,64,70]$. A low-speed machining setup is readily available and more economical as compared to a high-speed machining setup. Hence, this research aims to fill the gap in the literature and investigate the effect of low cutting speed (in the conventional machining range) to study the effect of tool coating and process parameters on burr formation and surface roughness below the cutting-edge radius.

\section{Materials and Methods}

\subsection{CNC Machine Details and Setup}

The micromilling experiments were performed on Inconel 718 (nickel alloy) using conventional speed machining center FANUC MV-1060. A FANUC 0i-MC motion controller was used to control the relative motion between the workpiece and milling tool during the micromachining process. First, a carbide end mill of $12 \mathrm{~mm}$ diameter was used to level the surface of the workpiece, and then that surface was taken as reference. A tool presetter was used for accurate measurements in the $z$-axis. Experimental conditions for these tests are given in Table 2.

Table 2. Experimental conditions and setup.

\begin{tabular}{cc}
\hline Workpiece Material & Inconel 718 \\
\hline Tool Diameter $(\mathrm{mm})$ & 0.5 \\
\hline Number of flutes & 2 \\
\hline Cutting Length $(\mathrm{mm})$ & 10 \\
\hline Cutting condition & Dry cutting (no coolant) \\
\hline Milling Type & Full Immersion \\
\hline
\end{tabular}

The dimension of the workpiece that was mounted on the fixture was $10 \mathrm{~mm} \times 50 \mathrm{~mm} \times 20 \mathrm{~mm}$, which was prepared using Electric Discharge Machining (EDM). The cutting length of these slots for the experimentations was fixed at $10 \mathrm{~mm}$, so the wear and damage to the tool can be neglected. Each slot was $2 \mathrm{~mm}$ apart, as shown in Figure 1. 


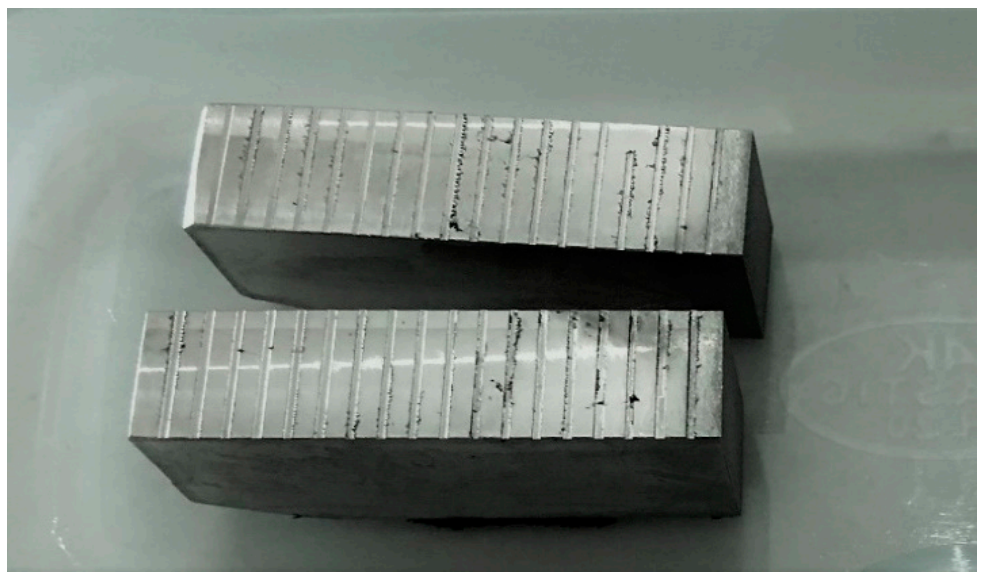

Figure 1. Sample of the machined workpiece.

Four factors were investigated to find their effects on burr formation and surface roughness. These factors are (a) three different tool coatings, (b) three levels of feed rate ( $\mu \mathrm{m} /$ tooth) below the cutting-edge radius, (c) three levels of cutting speed in conventional cutting speed range and (d) three levels of depth of cut. Details of these parameters and their levels are given in Table 3. In this research, Analysis of Variance (ANOVA) was used to find the influence of each parameter on burr formation and surface analysis, and the Taguchi method was used to find the best parameters for minimum burr formation and surface roughness. It uses a special method to study the entire range of parameters with a limited number of experiments using orthogonal arrays. These 9 trials were performed twice to check the repeatability of the experiments.

Table 3. Details of machining parameters.

\begin{tabular}{ccccc}
\hline Parameter & Units & Level 1 & Level 2 & Level 3 \\
\hline Cutting speed $(V \mathrm{c})$ & $\mathrm{m} / \mathrm{min}$ & 8 & 10 & 12 \\
\hline Feed rate $(f)$ & $\mu \mathrm{m} /$ tooth & 0.2 & 0.6 & 1 \\
\hline Depth of cut $(a \mathrm{p})$ & $\mu \mathrm{m}$ & 30 & 60 & 90 \\
\hline Coating $\left(\mathrm{t} \_\mathrm{c}\right)$ & - & AlTiN & TiSiN & nACo \\
\hline
\end{tabular}

\subsection{Workpiece Material Preparation and Characteristics}

First, the work material was ground and polished. After that, waterless kalling's agent was used for itching for almost $5 \mathrm{~s}$ and then cleaned with water. The average grain size was measured to be $22.5 \mu \mathrm{m}$ using an optical microscope (Optika B-600 MET, Ponteranica (BG), Italy) by using the ASTM standard method [79]. A Vickers Microhardness tester (HBRVU187.5 Times Group Inc., Beijing, China) was used to find the Vickers hardness of Inconel 718. Five tests were conducted in different areas to ensure accuracy. Dwell time was $6 \mathrm{~s}$, and $9800 \mathrm{mN}$ force was used during these tests. Microhardness was found to be $361 \mathrm{HV}$.

\subsection{Cutting Tool Specifications}

The cutting tools material was made from tungsten carbide flat end mills (K44\&K40, Osaka, Japan) with a tool diameter of $0.5 \mathrm{~mm}$; images of the cutting tools used in the current study are shown in Figure 2.

The average cutting-edge radius found for the microtools was AlTiN coated tool $=1.21 \mu \mathrm{m}$, TiSiN coated tool $=3 \mu \mathrm{m}$ and nACo coated tool $=1.3 \mu \mathrm{m}$. The specifications of the micromilling end tool are given in Table 4. The details of the three types of tool coatings that were used during the experimentation process are given in Table 5. 
nACo

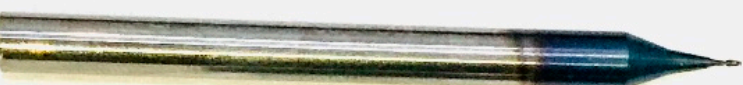

AlTiN

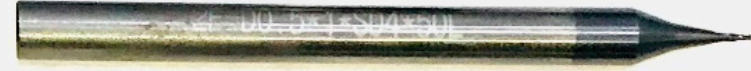

TiSiN

Figure 2. Different coated microdrill tools used in the experiments.

Table 4. Cutting tool details and specifications.

\begin{tabular}{cc}
\hline Detail & Information \\
\hline Brand name & NIKKEN \\
\hline Material & Tungsten carbide steel \\
\hline Type & End mill \\
\hline Number of flutes & 2 \\
\hline Diameter $(\mathrm{mm})$ & 0.5 \\
\hline Overall length $(\mathrm{mm})$ & 50 \\
\hline Rockwell hardness $(\mathrm{HRC})$ & 60 \\
\hline Cobalt content $(\%)$ & 12 \\
\hline Blade length $(\mathrm{mm})$ & 1 \\
\hline Helix angle $\left({ }^{\circ}\right)$ & 35 \\
\hline Grain size $(\mu \mathrm{m})$ & 0.5 \\
\hline Flexural Strength $(\mathrm{N} / \mathrm{mm})$ & 4300 \\
\hline
\end{tabular}

Table 5. Coatings specification used in the study.

\begin{tabular}{cccc}
\hline Item & AlTiN & TiSiN & nACo \\
\hline Hardness $(\mathrm{HV})$ & 3200 & 3600 & 4500 \\
\hline Thickness (microns) & $2.5-3$ & 3 & 3 \\
\hline Oxidation temp $\left({ }^{\circ} \mathrm{C}\right)$ & 900 & 1000 & 1200 \\
\hline Friction coefficient & 0.3 & 0.45 & 0.4 \\
\hline Color & Black & Golden & Blue \\
\hline
\end{tabular}

\subsection{Burr Formation Measurement}

There are different locations at which burr can form such as a top burr, exit burr, entrance burr, and bottom burr. In the current experimentations, during the burr analysis, the focus was given to the top burr width and was measured using a scanning electron microscope (TESCAN VEGA3, kohoutovice, Czech Republic) at different magnifications according to the width of the burr. During burr formation analysis, maximum burr width was measured for each slot as shown in Figure 3. 


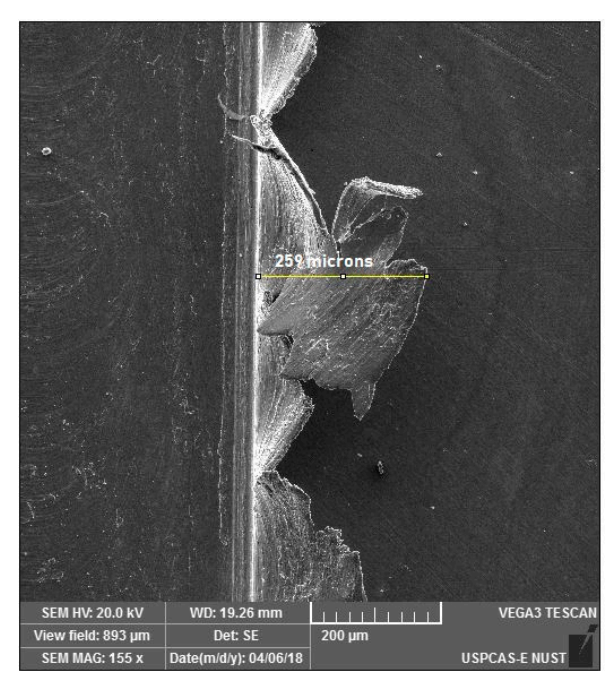

Figure 3. Burr width measurement $\left(a_{\mathrm{P}}=30 \mu \mathrm{m}, V_{\mathrm{C}}=8 \mathrm{~m} / \mathrm{min}, f_{Z}=0.2 \mu \mathrm{m} /\right.$ tooth, TiSiN $)$.

\subsection{Surface Roughness Measurement}

The surface roughness of all the slots was measured using an optical profilometer (Nanoeva, CA, USA) as it allows the identification of microsurface textures in micromilling operation. The surface roughness value was measured at the start of machined slots to mitigate any effects due to tool wear. Surface roughness values were measured in nanometers. The standard used to calculate surface roughness is ISO 4287 . The specifications of the optical profilometer used is given in Table 6.

Table 6. Optical profilometer specification.

\begin{tabular}{cc}
\hline Brand & Nanovea \\
\hline Model & PS 50 \\
\hline Test Facility & Thickness and topography of thin films \\
\hline$X-Y$ Axis Travel & $50 \mathrm{~mm}$ \\
\hline$X-Y$ Axis Resolution & $0.1 \mu \mathrm{m}$ \\
\hline Vertical Resolution & $12 \mathrm{~nm}$ \\
\hline
\end{tabular}

\subsection{Methodology}

In this study, ANOVA was used to find the significance of each parameter on burr formation and the Taguchi method was used to find the best parameters for minimum burr formation. The $\mathrm{S} / \mathrm{N}$ ratio is used in the Taguchi method to find the variations in experimental design. Calculating the $\mathrm{S} / \mathrm{N}$ ratio depends on the type of results. There are three types of formulas used to find the $\mathrm{S} / \mathrm{N}$ ratio-i.e., the smaller the better, the more nominal the better and the larger the better. In the current work, the smaller the better was used to find the $\mathrm{S} / \mathrm{N}$ ratio since smaller values of the burr width are required.

$$
\text { S/N Ratio }=-10 \log _{10}\left(\sum_{i=1}^{n} Y_{i}^{2} / n\right)
$$

where:

- $\quad i=$ the value measured in $i$ th number;

- $n=$ total number of repeated experiments.

The mean of the $\mathrm{S} / \mathrm{N}$ ratio for each level was calculated by taking the average of the $\mathrm{S} / \mathrm{N}$ ratio values at their corresponding levels. The best parameters were selected by choosing the maximum mean of S/N ratio values. Taguchi's L9 orthogonal array was 
used to define the 9 trials. ANOVA was used to find the percentage contribution of each parameter on burr formation and surface roughness. $p$-values (probability values) were found for each parameter to find its significance on results based on a $95 \%$ confidence level. This means that if the $p$-value for a cutting parameter is found to be less than 0.05 , then it has a confidence level of $95 \%$ or above; hence, it would be considered a significant factor.

\section{Results and Discussion}

Table 7 shows the results obtained for burr width and surface roughness. All the experiments were repeated and then their average was reported in the analysis. It was observed that the results from the first and second runs varied significantly, mainly because of variation in tool quality, machine noise, human error when measuring and fixing the depth of cut. Small errors and noise greatly affected the results in micromachining processes due to their increased sensitivity.

Table 7. Experimental plan using an L9 orthogonal array and the corresponding surface roughness.

\begin{tabular}{|c|c|c|c|c|c|c|c|c|}
\hline \multicolumn{5}{|c|}{ Input Parameters } & \multicolumn{2}{|c|}{ Surface Roughness (nm) } & \multicolumn{2}{|c|}{ Burr Width $(\mu \mathrm{m})$} \\
\hline Trail & $a_{\mathrm{p}}(\mu \mathrm{m})$ & $V_{\mathrm{c}}(\mathrm{m} / \mathrm{min})$ & $f_{\mathrm{z}}(\mu \mathrm{m} /$ tooth $)$ & $\left(t \_c\right)$ & Run 1 & Run 2 & Run 1 & Run 2 \\
\hline 1 & 30 & 8 & 0.2 & AlTiN & 128 & 138 & 259 & 172 \\
\hline 2 & 30 & 10 & 0.6 & TiSiN & 313 & 212 & 399 & 500 \\
\hline 3 & 30 & 12 & 1 & nACo & 106 & 119 & 423 & 497 \\
\hline 4 & 60 & 8 & 0.6 & nACo & 142 & 213 & 215 & 135 \\
\hline 5 & 60 & 10 & 1 & AlTiN & 180 & 184 & 240 & 181 \\
\hline 6 & 60 & 12 & 0.2 & TiSiN & 102 & 97 & 404 & 196 \\
\hline 7 & 90 & 8 & 1 & TiSiN & 104 & 160 & 200 & 145 \\
\hline 8 & 90 & 10 & 0.2 & nACo & 335 & 487 & 180 & 156 \\
\hline 9 & 90 & 12 & 0.6 & AlTiN & 190 & 200 & 288 & 210 \\
\hline
\end{tabular}

ANOVA was used to find the percentage effect of parameters on the results. The ANOVA results shown in Tables 8 and 9 indicate the cutting parameters that had the most significant effect on the surface roughness and burr formation.

Table 8. Analysis of Variance (ANOVA) for surface roughness.

\begin{tabular}{cccccccccc}
\hline Source & DF & Seq SS & Contribution & Adj SS & Adj MS & F-Value & $p$-Value & Significance \\
\hline$a_{\mathrm{p}}$ & 2 & 29,587 & $17.28 \%$ & 29,587 & 14,794 & 6.36 & 0.019 & Significant \\
\hline$V_{\mathrm{c}}$ & 2 & 82,885 & $48.40 \%$ & 82,885 & 41,442 & 17.81 & 0.001 & Significant \\
\hline$f_{\mathrm{z}}$ & 2 & 20,141 & $11.76 \%$ & 20,141 & 10,070 & 4.33 & 0.048 & Significant \\
\hline $\mathrm{t} \_\mathrm{c}$ & 2 & 17,686 & $10.33 \%$ & 17,686 & 8843 & 3.80 & 0.064 & Not Significant \\
\hline Error & 9 & 20,946 & $12.23 \%$ & 20,946 & 2327 & - & - & - \\
\hline Total & 17 & 171,244 & $100.00 \%$ & - & - & - & & - \\
\hline
\end{tabular}

Table 9. ANOVA for burr formation.

\begin{tabular}{ccccccccc}
\hline Source & DF & Seq SS & Contribution & Adj SS & Adj MS & F-Value & $p$-Value & Significance \\
\hline$a_{\mathrm{p}}$ & 2 & 108,697 & $42.95 \%$ & 108,697 & 54,349 & 11.37 & 0.003 & Significant \\
$V_{\mathrm{c}}$ & 2 & 67,089 & $26.51 \%$ & 67,089 & 33,545 & 7.01 & 0.015 & Significant \\
$f_{\mathrm{z}}$ & 2 & 13,882 & $5.49 \%$ & 13,882 & 6941 & 1.45 & 0.284 & Not Significant \\
t_c & 2 & 20,345 & $8.04 \%$ & 20,345 & 10,173 & 2.13 & 0.175 & Not Significant \\
Error & 9 & 43,038 & $17.01 \%$ & 43,038 & 4782 & - & - & - \\
Total & 17 & 253,052 & $100.00 \%$ & - & - & - & - & - \\
\hline
\end{tabular}




\subsection{Surface Roughness}

During the machining of metals, surface roughness was mainly affected by the feed rate to -cutting-edge radius, cutting speed, depth of cut and tool coatings [32,45,48,80,81]. It was also affected by tool wear when the cutting-edge radius increased and the feed rate $(\mu \mathrm{m} /$ tooth) decreased $[44,48]$. Surface finish was also influenced by BUE in which the chips are welded to the machine surface and deteriorate the surface quality. It is also of great concern when the welded chip eventually detaches from the surface and leaves small holes, which greatly affects the surface quality [60].

The effect of cutting parameters and tool coating on surface roughness is given in Figure 4. It was found from the main effect plot that the slot machined by TiSiN coated tools gave minimum surface roughness values during the micromachining of Inconel 718 for a cutting length of $10 \mathrm{~mm}$. This is due to the higher coefficient of friction value compared to the other tool which might have caused an increase in cutting temperature [82]. A higher cutting temperature helps the material to easily deform and most of the feed/tooth are below the cutting-edge radius; thus, the material removal occurs by chip deformation. This type of chip leads to an increase in burr formation but in return it decreases the surface roughness due to rubbing of the tool with the workpiece and easy chip deformation with no groves. Therefore, minimum surface roughness was found when cutting at a higher speed and using the TiSiN coated tool. The AlTiN coated tool showed the next best result for surface roughness which is almost comparable to that of TiSiN coated tools. nACo coated tools showed higher values for surface roughness. This could be attributed to the higher hardness of nACo tools relative to the other two coatings. It was also observed that the BUE formations on the surfaces machined by nACo coated tools were greater than those found on the surfaces machined using TiSiN and AlTiN coated tools, which might be the reason for the higher surface roughness.

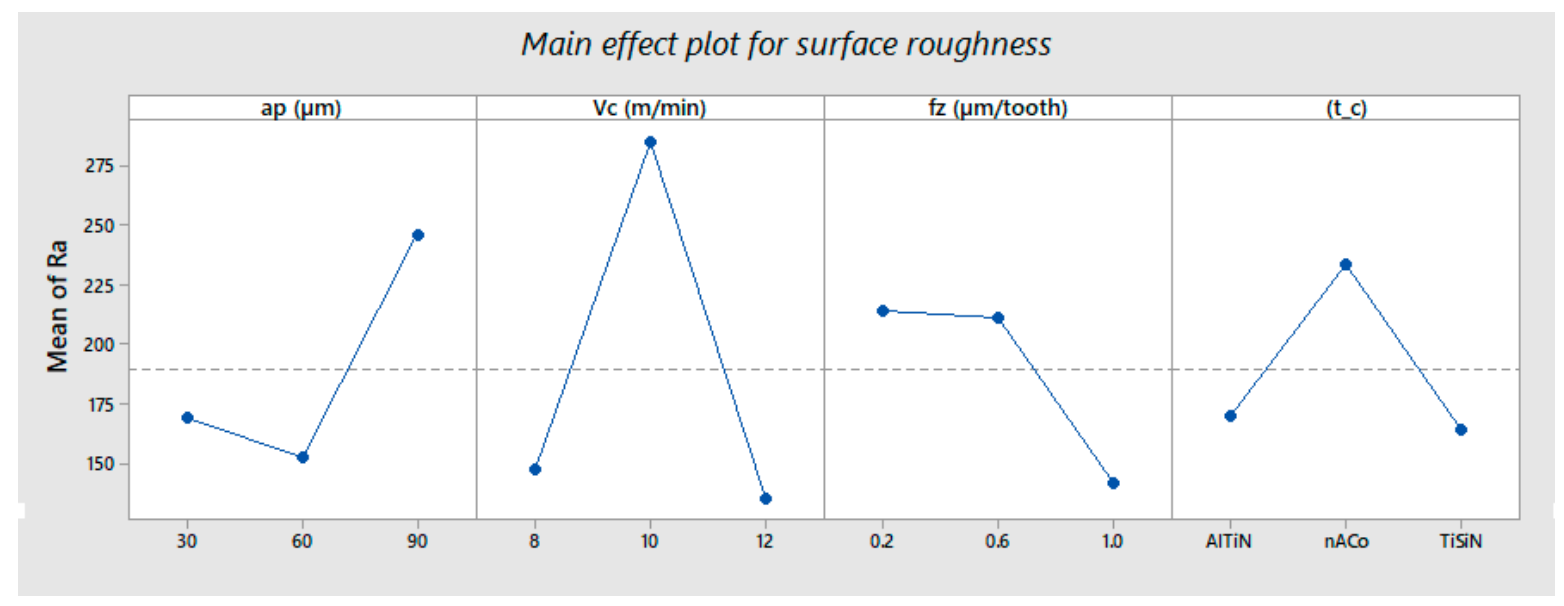

Figure 4. Main effect plot for surface roughness.

A high temperature is produced during micromachining processes at a higher axial depth of cut due to an increase in friction between the workpiece and cutting-edge of the tool. It also increases the cutting force and tool vibration which causes the increase in surface roughness values [32,48]. A good surface finish is produced up to the minimum chip thickness but, below that point, the surface roughness starts to increase due to an increase in ploughing and cutting force [72]. The minimum chip thickness for Inconel 718 is almost $20 \%$ to $25 \%$ of the cutting-edge radius [83]. Below the minimum chip thickness, the workpiece starts to deform and proper chips are not formed as a result of this which causes the formation of built-up edges which eventually leads to a poor surface.

One of the most important parameters that affect the surface roughness is the cuttingedge radius of the tool [84]. The cutting-edge radii of AlTiN and nACo coated tools are almost the same-i.e., around $1.2 \mu \mathrm{m}$-and the TiSiN coated tool has a radius of around 
$3 \mu \mathrm{m}$. As a result, the minimum chip thickness for TiSiN was found to be $0.6 \mu \mathrm{m} /$ tooth and $0.32 \mu \mathrm{m} /$ tooth for AlTiN and nACo coated tools. For the TiSiN coated tool, the feed rate $(\mu \mathrm{m} /$ tooth $)$ matches the minimum chip thickness and the other two are below and above minimum chip thickness, whereas for the AlTiN and nACo coated tools, one feed rate $(\mu \mathrm{m} /$ tooth $)$ is above the minimum chip thickness and one is below. Micromilling on minimum chip thickness gives good surface roughness than when milling below and above minimum chip thickness because the minimum cut occurs with no elastic deformation which produces a clearer surface without any ploughing [83]. This might also explain the lower surface roughness values for TiSiN coated tools.

From ANOVA results on surface roughness, it was concluded that the cutting speed was the most dominant factor that affects the surface roughness values, with $48 \%$ of the total variability as shown in the literature [81]. This is due to a change in temperature which is mostly affected by the cutting speed that in return influences the surface roughness [85]. The axial depth of cut was the second most dominant factor affecting surface roughness values which is almost $17 \%$ of the total variability. The feed rate $(\mu \mathrm{m} /$ tooth $)$ and the type of coating effect on surface roughness were lower with percentage contributions of $22 \%$ for both. Tool coating contributed less to surface roughness compared to that of cutting velocity; this is due to a lower contribution of the tool coating coefficient of friction in heat generation compared to the other cutting parameters. Moreover, the tool coating does not affect other aspects of the cutting mechanism. From the literature, it was observed that the depth of cut does not have a substantial effect on surface roughness and cannot be determined due to its irregular results [32,45]. In some studies, it was also seen that at a very small depth of cut the surface roughness was more due to an increased ploughing effect and as the depth of cut increases the ploughing effect was diminished and proper cutting took place which resulted in a reduction in surface roughness [72]. However, increasing the depth of cut increased the cutting force and vibration at the cutting zone which resulted in a poor surface finish $[32,48]$.

It was concluded from the main effect plot that the surface roughness increased with the increase in cutting speed from 8 to $10 \mathrm{~m} / \mathrm{min}$ and then decreased from 10 to $12 \mathrm{~m} / \mathrm{min}$. It was also observed from the literature that the surface roughness decreased from 10 to $25 \mathrm{~m} / \mathrm{min}$ [81]. From the given results, it was also determined that the surface roughness decreased with a ratio of undeformed chip thickness $(f z)$ to -cutting-edge radius $(r e)(f z / r e)$ of 0.3 to 0.5 , as reported in the literature, compared to the results shown in Figure 5 [81].

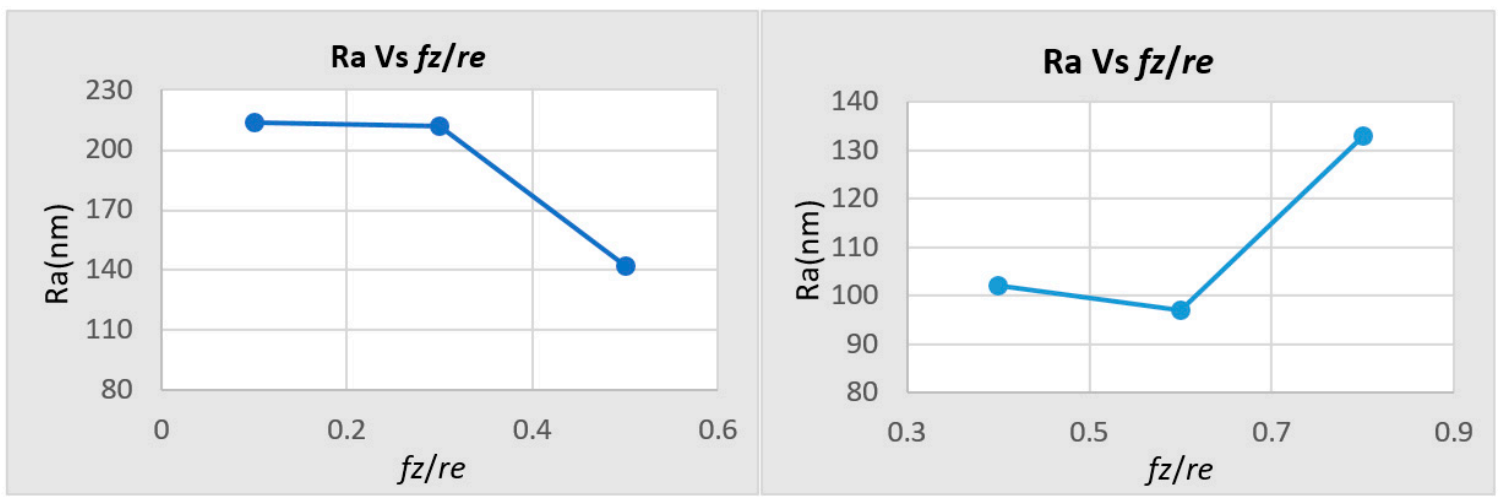

Figure 5. Comparison for the main effect plot for Ra vs. undeformed chip thickness $(f z)$ to cutting-edge radius $(r e)(f z / r e)$ with the literature [81] (with the permission of Elsevier).

\subsection{Burr Formation Analysis}

ANOVA was used for burr analysis in which the burr width was the response variable. During the experimentation, most of the burr formed was during down milling, the same as observed in the literature [86]. The focus of this research during burr analysis is the 
top burr. The maximum burr width of each slot was measured using a scanning electron microscope.

Figure 6 shows the main effect plot for burr width, it can be seen that AlTiN coated tools showed the best performances for the burr formation during micromachining of Inconel 718 for the cutting length of $10 \mathrm{~mm}$. nACo coated tools showed higher burr values than AlTiN coated tools and less than TiSiN coated tools. The TiSiN coated tool showed higher values for burr formation due to the larger cutting-edge radius compared to the other tools, which indicates that cutting-edge radius is a significant cutting parameter in the micromilling process. Due to the larger cutting-edge radius, most of the cutting was below the minimum chip thickness which increased the cutting forces and deformation during the machining process and, therefore, resulted in a larger burr width.

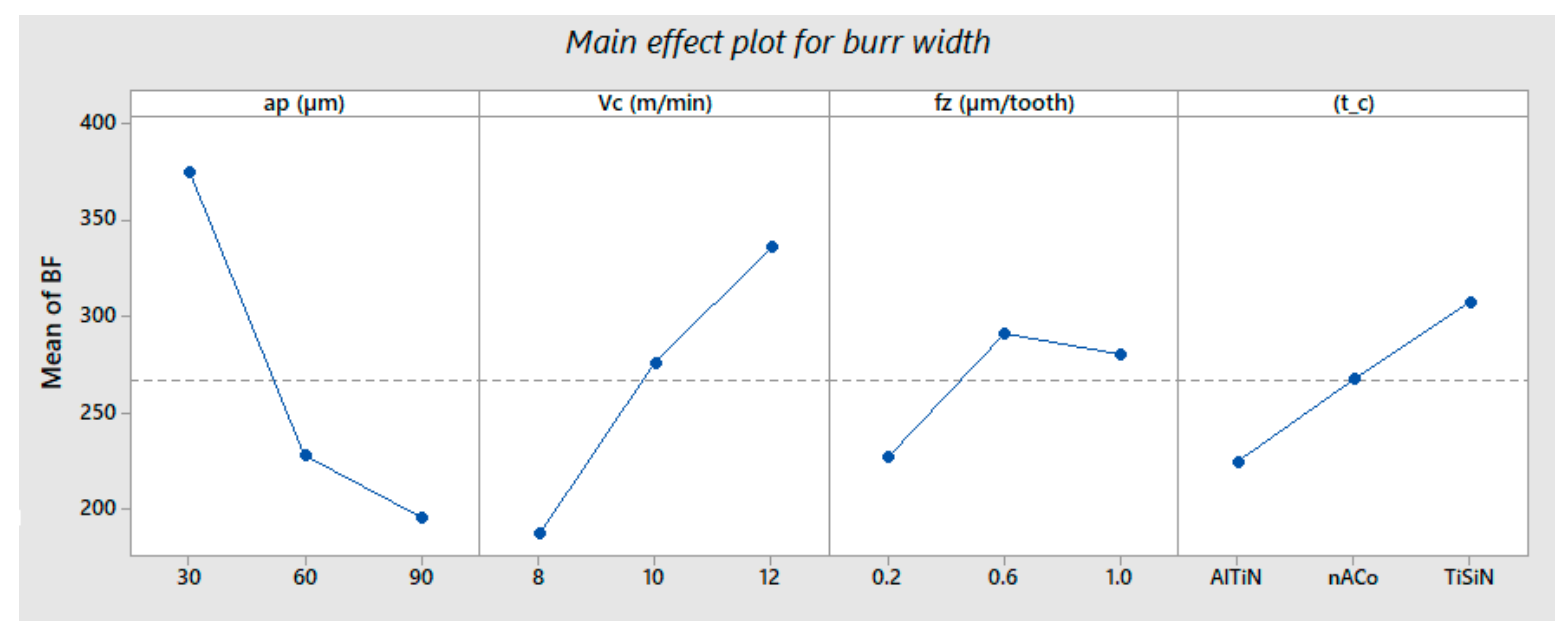

Figure 6. Main effect plot for burr width.

ANOVA results on burr formation reveal that the axial depth of cut is the most dominant factor in burr formation, accounting for $43 \%$ of the total variability. Cutting velocity was found to be the second most dominant factor affecting burr formation values with $26 \%$ of the total variability. Feed rate $(\mu \mathrm{m} /$ tooth) and type of coating effect on burr formation contributions were low, with $14 \%$ for both. Tool coating and feed rate $(\mu \mathrm{m} /$ tooth $)$ were found to be insignificant parameters.

Figure 6 shows the main effect plot for burr width from which it was observed that the burr width decreased with the increase in depth of cut during micromachining of Inconel 718. Burr is a form of the uncut chip so as the depth of cut increases the length of the chip increases, which allows it to be easily chipped off from the worked piece; therefore, less burr was formed at a high depth of cut as compared to the small depth of cut.

It was also observed that increasing the cutting speed increased the formation of burr. This is due to the difference in cutting temperature at different cutting speeds. The cutting temperature between the workpiece and tool edge is high during high-speed machining which helps the workpiece to deform more and causes a larger burr width. The TiSiN coated tool had higher friction of coefficient which helped in material deformation due to the increase in temperature and consequently increased burr formation [85]. It was also observed that as the feed rate increased, the burr width first increased and then decreased.

It was observed that as the feed to cutting-edge radius values increased from 0.3 to 0.5 , the burr width decreased. The same trend was observed for burr root thickness during micromachining of Inconel 718 in a previous study, as shown in Figure 7 [81]. 


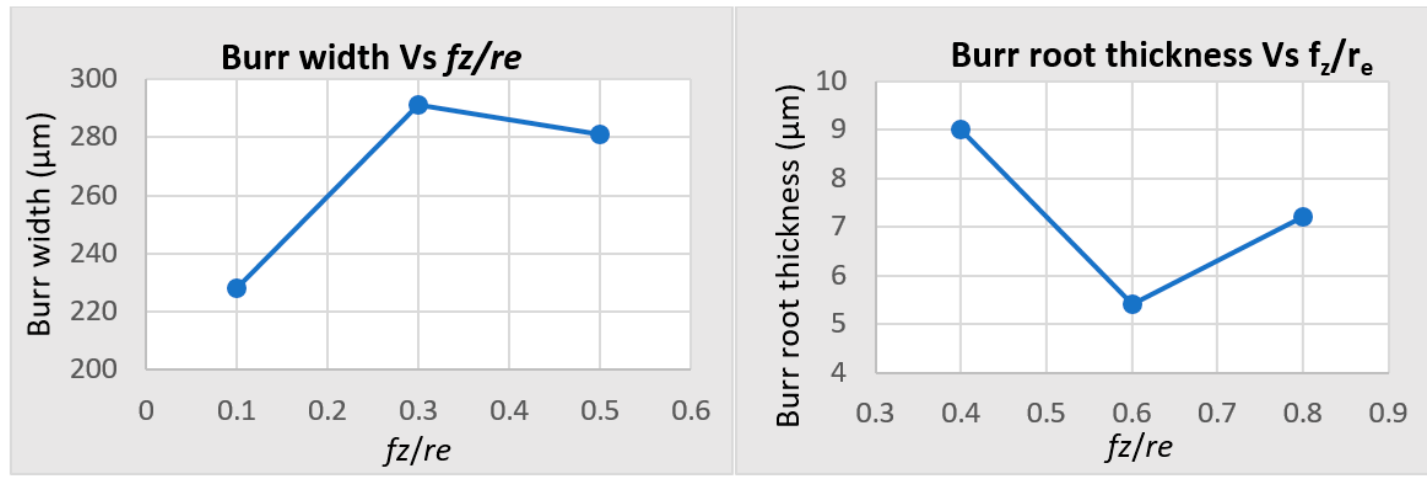

Figure 7. Main effect plot for $f z / r e$ vs. burr width [81] (with the permission of Elsevier).

Generally, three main types of burrs were observed during experimentation: rollover burr, Poisson burr and feathery Burr, as shown in Figure 8. The rollover burr type is produced when the chip is formed by pushing the material out of the cutter path rather than sharing [84]. This type of burr was produced with medium to low axial depths of cut and with a low feed rate $(\mu \mathrm{m} /$ tooth) to -cutting-edge radius ratio.

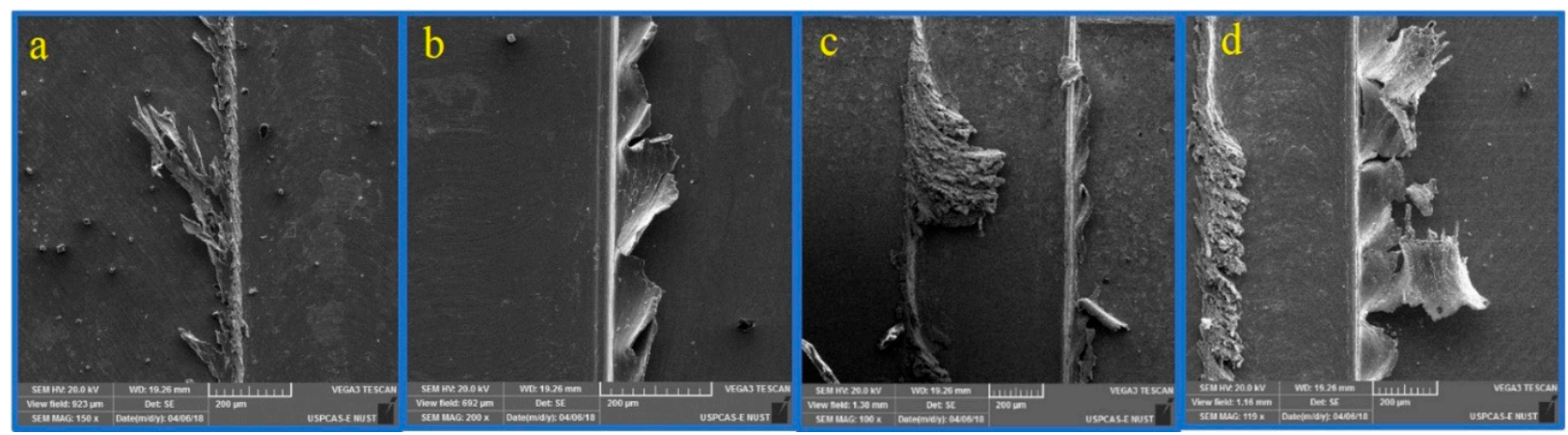

Figure 8. Burr types observed in the study: (a) Feathery burr $\left(a_{\mathrm{P}}=10 \mu \mathrm{m}, V_{\mathrm{C}}=8 \mathrm{~m} / \mathrm{min}, f_{\mathrm{Z}}=1 \mu \mathrm{m} /\right.$ tooth, $\left.\mathrm{nACo}\right)$; (b) rollover burr $\left(a_{\mathrm{P}}=30 \mu \mathrm{m}, V_{\mathrm{C}}=10 \mathrm{~m} / \mathrm{min}, f_{\mathrm{Z}}=0.6 \mu \mathrm{m} /\right.$ tooth, AlTiN); (c) Poisson burr $\left(a_{\mathrm{P}}=90 \mu \mathrm{m}, V_{\mathrm{C}}=10 \mathrm{~m} / \mathrm{min}\right.$, $f_{\mathrm{Z}}=0.2 \mu \mathrm{m} /$ tooth, AlTiN); (d) rollover burr/Poisson burr $\left(a_{\mathrm{P}}=60 \mu \mathrm{m}, V_{\mathrm{C}}=12 \mathrm{~m} / \mathrm{min}, f_{\mathrm{Z}}=0.2 \mu \mathrm{m} /\right.$ tooth, TiSiN).

The Poisson type burr is produced by the tendency of the material to bulge at the side when the material is compressed until permanent deformation occurs [55]. This type of cut and lower feed rate ( $\mu \mathrm{m} /$ tooth) to -cutting-edge radius ratio. The feathery type burr is produced when the material removal is by tearing rather than sharing [84]. This type of burr was observed at a low axial depth of cut and high feed rate ( $\mu \mathrm{m} /$ tooth) to -cuttingedge radius. Cutting speed was not significant for different types of burr in the range of 8 to $12 \mathrm{~m} / \mathrm{min}$. Burr is a type of uncut chip, so as the depth of cut increases, the chip length increases. This influences the burr width which is the main reason that the depth of cut influences the parameter during the micromilling process. The depth of cut also influences the type of burr produced because as the depth of cut increases, the cutting temperature increases which help in material deformation.

Confirmation experiments were performed using both the best and the worst cutting parameters found by using Design of experiments (DOE), Taguchi method and ANOVA. Table 10 shows the results of these confirmation experiments for both the surface roughness and burr formation. The confirmation results for the surface roughness were compared to the results in Table 7 . It was found that the results from the optimum cutting parameters were better than those of the previous experiments. A decrease was observed in the surface roughness from 100 to $94.5 \mu \mathrm{m}$ ( $6.5 \%$ reduction), which is the lowest surface roughness value in Table 7 . For the worst parameters, there was no increase in surface roughness because the worst parameters found were also in the design of experiments. For the 
optimal cutting condition, the burr size was half that of the minimum burr size found (Table 7). As for the worst cutting parameters, there was an increase of almost $100 \mu \mathrm{m}$ in burr size compared to the maximum burr size found (Table 7). It can be also concluded that the Taguchi and ANOVA methods can help obtain optimum cutting parameters to increase the machining quality from a given range of parameters with a limited number of experiments [87].

Table 10. Confirmation experiments for the burr and surface roughness tests.

\begin{tabular}{|c|c|c|c|c|c|c|c|c|}
\hline \multirow{2}{*}{ Experiment } & \multicolumn{6}{|c|}{ Input Parameters } & \multicolumn{2}{|c|}{ Results } \\
\hline & $a_{\mathrm{p}}(\mu \mathrm{m})$ & $V_{\mathrm{C}}(\mathrm{m} / \mathrm{min})$ & $f_{\mathrm{Z}}(\mu \mathrm{m} /$ tooth $)$ & Coating & Condition & Characteristic & Obs $1(\mu \mathrm{m})$ & Obs $2(\mu \mathrm{m})$ \\
\hline 1 & 90 & 8 & 0.2 & AlTiN & Best & Burr width & 72 & 93 \\
\hline 2 & 30 & 12 & 0.6 & TiSiN & Worst & Burr width & 649 & 459 \\
\hline 3 & 60 & 12 & 1 & TiSiN & Best & $\begin{array}{l}\text { Surface } \\
\text { roughness }\end{array}$ & 0.092 & 0.097 \\
\hline 4 & 90 & 10 & 0.2 & nACo & Worst & $\begin{array}{l}\text { Surface } \\
\text { roughness }\end{array}$ & 0.335 & 0.487 \\
\hline
\end{tabular}

There were little to no burrs found for the best cutting conditions which are due to the proper cut at $a_{\mathrm{p}}=90 \mu \mathrm{m}$ and cutting speed of $8 \mathrm{~m} / \mathrm{min}$ which is speculated to generate lower cutting temperatures which in return tends to produce less deformations. There were two types of burr observed during the worst cutting condition-namely, Poisson's and rollover burrs. These types of burrs were caused by the high-temperature deformation and compression due to high cutting speed and small depth of cut [84]. In conclusion, it is speculated that the high temperatures that developed at the cutting zone and low depth of cut are responsible for the increased deformation along the path of cutting, as shown in Figure 9a.

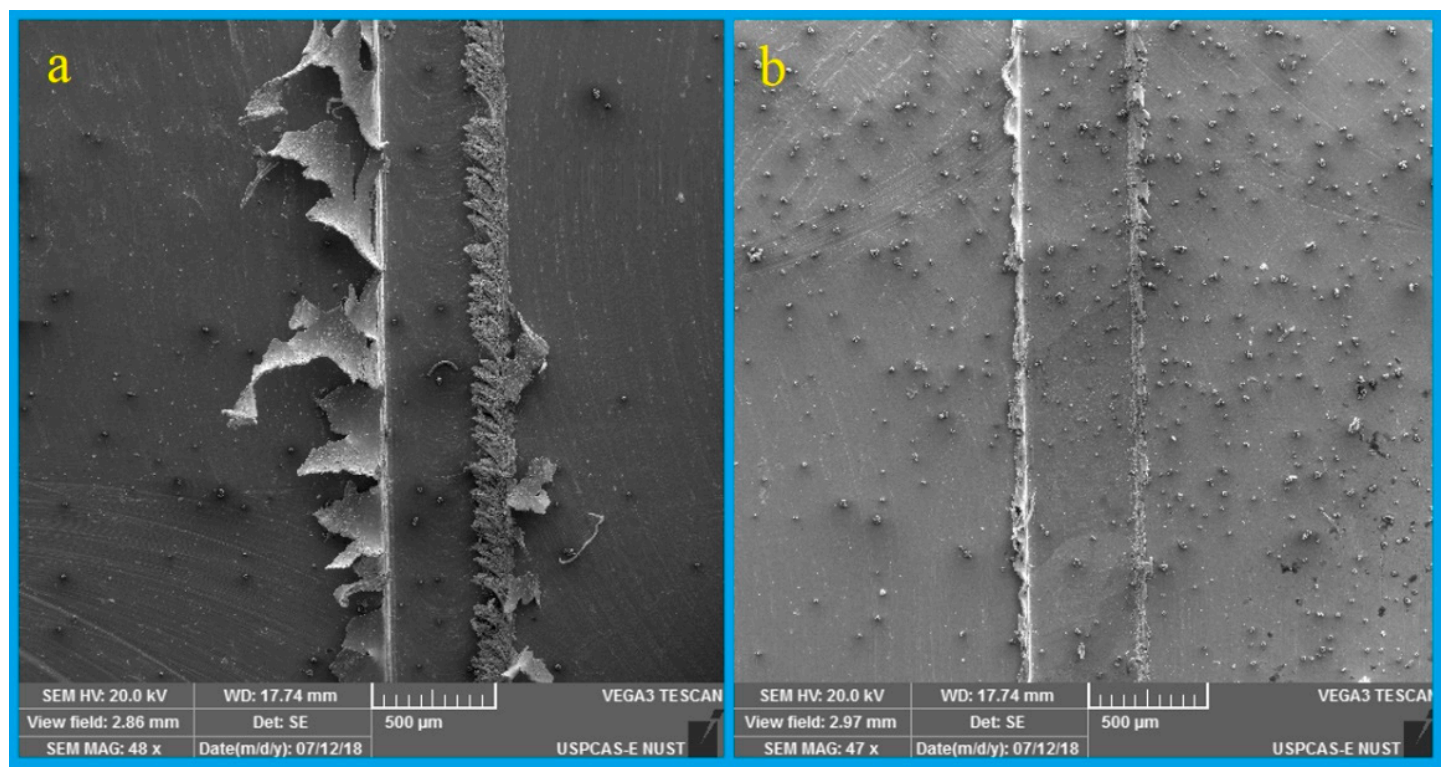

Figure 9. SEM images for confirmation experiments showing: (a) severe burr formation for worst cutting conditions $\left(a_{\mathrm{P}}=30 \mu \mathrm{m}, V_{\mathrm{C}}=12 \mathrm{~m} / \mathrm{min}, f_{\mathrm{Z}}=0.6 \mu \mathrm{m} /\right.$ tooth$) ;(\mathbf{b})$ minor burr formation at optimum cutting conditions $\left(a_{\mathrm{P}}=90 \mu \mathrm{m}\right.$, $V_{\mathrm{C}}=8 \mathrm{~m} / \mathrm{min}, f_{\mathrm{Z}}=0.2 \mu \mathrm{m} /$ tooth).

\section{Conclusions}

The current study aims to determine the effect of different tool coatings and cutting parameters on burr formation and surface roughness during the micromachining of Inconel 718 using an end mill tool with a diameter of $0.5 \mathrm{~mm}$. The micromilling experiments were performed at low speeds and with feed rates ( $\mu \mathrm{m} /$ tooth) below the cutting-edge radius 
since this combination of conditions has not been widely reported in previous literature. The following can be concluded from the experimental work and the statistical analysis carried out using ANOVA:

- Cutting velocity was found to be the most dominant factor in minimizing the surface roughness and axial depth of cut was found to be the most dominant factor for reducing burr formation, which is almost $50 \%$ of the total variability;

- During ANOVA of the surface roughness cutting velocity, the axial depth of cut and feed rate ( $\mu \mathrm{m} /$ tooth) were found to be the most significant parameters with a confidence level of more than $95 \%$;

- For burr formation, the axial depth of cut and cutting velocity were found to be the most significant parameters with a confidence level of more than $95 \%$, whereas feed rate $(\mu \mathrm{m} /$ tooth $)$ was not found to be a significant parameter for reducing the burr width;

- Tool coating was found not to be a significant parameter for both burr formation and surface roughness with a contribution percentage of around $10 \%$ at low-speed machining;

- Types of burr formed during experimentation were mainly affected by the axial depth of cut, feed rate ( $\mu \mathrm{m} /$ tooth) and were not affected by cutting velocity and tool coating;

- It also has been concluded that the results for the surface finish at low-speed machining are comparable to that of transition and high-speed machining and good results were found for the burr width during confirmation experiments at low-speed machining;

- From this study, it was also concluded that the coefficient of friction of the tool coating plays an important role in increasing and decreasing the surface roughness and burr formation during micromilling of Inconel 718 at low speed. It is speculated that a high coefficient of friction increases the machining temperature and helps the material to easily deform, but it also increases the burr formation.

Author Contributions: Conceptualization, A.M. and K.G.; Formal analysis, A.M. and D.Y.P.; Investigation, K.G.; Methodology, A.M.; Software, A.M.; Supervision, K.G.; Validation, A.M., M.K.G. and T.M.; Writing—original draft, A.M. and K.G.; Writing—review and editing, M.K.G., T.M., D.Y.P. and K.G. All authors have read and agreed to the published version of the manuscript.

Funding: This research received no external funding.

Data Availability Statement: Data can be made available upon request.

Conflicts of Interest: The authors declare no conflict of interest.

$\begin{array}{ll}\text { Abbreviations } \\ a_{\mathrm{p}} & \text { Axial depth of cut } \\ \mathrm{CR} & \text { Contribution ratio } \\ \mathrm{D} & \text { Tool diameter } \\ \mathrm{d} f & \text { Degree of freedom } \\ f_{\mathrm{z}} & \text { Feed rate } \\ F \text {-ratio } & \text { Fisher's ratio (variance) } \\ \mathrm{MSS} & \text { Mean sum of squares } \\ \mathrm{N} & \text { Spindle r/min } \\ p \text {-value } & \text { Confidence level } \\ \mathrm{R}_{\mathrm{a}} & \text { Surface roughness } \\ \mathrm{SS} & \text { Sum of squares } \\ t_{\mathrm{min}} & \text { Minimum chip thickness } \\ V_{\mathrm{c}} & \text { Cutting velocity } \\ L_{\mathrm{c}} & \text { Cutting length } \\ \mathrm{z} & \text { Number of teeth (milling cutter) } \\ \text { AlTiN } & \text { Titanium Aluminum Nitrate } \\ \end{array}$




$\begin{array}{ll}\text { TiSiN } & \text { Titanium Silicon Nitrate } \\ \text { nACo } & \text { Titanium Aluminum Nitrate + Silicon Nitrate } \\ \text { (t_c) } & \text { Tool coating } \\ \text { BUE } & \text { Built-up edge }\end{array}$

\section{References}

1. Chen, N.; Li, H.N.; Wu, J.; Li, Z.; Li, L.; Liu, G.; He, N. Advances in micro milling: From tool fabrication to process outcomes. Int. J. Mach. Tools Manuf. 2021, 160, 103670. [CrossRef]

2. Bhattacharyya, B. Chapter 1-Introduction. In Electrochemical Micromachining for Nanofabrication, MEMS and Nanotechnology; Bhattacharyya, B., Ed.; William Andrew Publishing: Norwich, NY, USA, 2015; pp. 1-23.

3. Mativenga, P. Micromachining. In CIRP Encyclopedia of Production Engineering; Springer: Berlin/Heidelberg, Germany, 2018; pp. 1-5.

4. Attanasio, A. Tool run-out measurement in micro milling. Micromachines 2017, 8, 221. [CrossRef] [PubMed]

5. Corbett, J.; McKeown, P.A.; Peggs, G.N.; Whatmore, R. Nanotechnology: International Developments and Emerging Products. CIRP Ann. 2000, 49, 523-546. [CrossRef]

6. Fu, G.; Huo, D.; Shyha, I.; Pancholi, K.; Saharudin, M.S. Experimental investigation on micro milling of polyester/halloysite nano-clay nanocomposites. Nanomaterials 2019, 9, 917. [CrossRef]

7. Samotaev, N.; Oblov, K.; Ivanova, A.; Podlepetsky, B.; Volkov, N.; Zibilyuk, N. Technology for SMD Packaging MOX Gas Sensors. Proceedings 2018, 2, 934. [CrossRef]

8. Chang, F.-Y.; Chen, Y.-C.; Liang, T.-H.; Cai, Z.-Y. Fabrication of Edge Rounded Polylactic Acid Biomedical Stents by the Multi-Axis Micro-Milling Process. Appl. Sci. 2020, 10, 2809. [CrossRef]

9. Jiménez-Díaz, E.; Cano-Jorge, M.; Zamarrón-Hernández, D.; Cabriales, L.; Páez-Larios, F.; Cruz-Ramírez, A.; Vázquez-Victorio, G.; Fiordelisio, T.; Hautefeuille, M. Micro-Macro: Selective Integration of Microfeatures Inside Low-Cost Macromolds for PDMS Microfluidics Fabrication. Micromachines 2019, 10, 576. [CrossRef]

10. Ling, S.; Li, M.; Liu, Y.; Wang, K.; Jiang, Y. Improving Machining Localization and Surface Roughness in Wire Electrochemical Micromachining Using a Rotating Ultrasonic Helix Electrode. Micromachines 2020, 11, 698. [CrossRef]

11. Bellotti, M.; Wu, M.; Qian, J.; Reynaerts, D. Tool Wear and Material Removal Predictions in Micro-EDM Drilling: Advantages of Data-Driven Approaches. Appl. Sci. 2020, 10, 6357. [CrossRef]

12. Allegri, G.; Colpani, A.; Ginestra, P.S.; Attanasio, A. An experimental study on micro-milling of a medical grade Co-Cr-Mo alloy produced by selective laser melting. Materials 2019, 12, 2208. [CrossRef]

13. Lei, J.; Jiang, K.; Wu, X.; Zhao, H.; Xu, B. Surface Quality Improvement of 3D Microstructures Fabricated by Micro-EDM with a Composite 3D Microelectrode. Micromachines 2020, 11, 868. [CrossRef] [PubMed]

14. Marrocco, V.; Modica, F.; Bellantone, V.; Medri, V.; Fassi, I. Pulse-Type Influence on the Micro-EDM Milling Machinability of Si3N4-TiN Workpieces. Micromachines 2020, 11, 932. [CrossRef]

15. Wu, M.; Saxena, K.K.; Guo, Z.; Qian, J.; Reynaerts, D. Fast Fabrication of Complex Surficial Micro-Features Using Sequential Lithography and Jet Electrochemical Machining. Micromachines 2020, 11, 948. [CrossRef]

16. Mian, A.J. Size Effect in Micromachining; The University of Manchester: Manchester, UK, 2011.

17. Bissacco, G.; Hansen, H.N.; De Chiffre, L. Size effects on surface generation in micro milling of hardened tool steel. CIRP Ann. 2006, 55, 593-596. [CrossRef]

18. Vogler, M.P.; DeVor, R.E.; Kapoor, S.G. On the modeling and analysis of machining performance in micro-endmilling, part I: Surface generation. J. Manuf. Sci. Eng. 2004, 126, 685-694. [CrossRef]

19. Weinert, K.; Petzoldt, V. Machining NiTi micro-parts by micro-milling. Mater. Sci. Eng. A 2008, 481, 672-675. [CrossRef]

20. Lu, X.; Wang, H.; Jia, Z.; Feng, Y.; Liang, S.Y. Coupled thermal and mechanical analyses of micro-milling Inconel 718. Proc. Inst. Mech. Eng. Part B J. Eng. Manuf. 2019, 233, 1112-1126. [CrossRef]

21. Lu, X.; Hu, X.; Jia, Z.; Liu, M.; Gao, S.; Qu, C.; Liang, S.Y. Model for the prediction of 3D surface topography and surface roughness in micro-milling Inconel 718. Int. J. Adv. Manuf. Technol. 2018, 94, 2043-2056. [CrossRef]

22. Jia, Z.; Lu, X.; Gu, H.; Ruan, F.; Liang, S.Y. Deflection prediction of micro-milling Inconel 718 thin-walled parts. J. Mater. Process. Technol. 2020, 291, 117003. [CrossRef]

23. Thulukkanam, K. Heat Exchanger Design Handbook; CRC Press: Boca Raton, FL, USA, 2013.

24. Czan, A. Identification of temperature in cutting zone when dry machining of Nickel alloy Inconel 718. Procedia Manuf. 2017, 14, 66-75. [CrossRef]

25. Shokrani, A.; Dhokia, V.; Newmana, S.T. Hybrid cooling and lubricating technology for CNC milling of Inconel 718 nickel alloy. Procedia Manuf. 2017, 11, 625-632. [CrossRef]

26. Pawade, R.S.; Joshi, S.S.; Brahmankar, P.K. Effect of machining parameters and cutting edge geometry on surface integrity of highspeed turned Inconel 718. Int. J. Mach. Tools Manuf. 2008, 48, 15-28. [CrossRef]

27. Kumar, S.; Singh, D.; Kalsi, N.S. Experimental investigations of surface roughness of Inconel 718 under different machining conditions. Mater. Today Proc. 2017, 4, 1179-1185. [CrossRef]

28. Sugihara, T.; Enomoto, T. High speed machining of Inconel 718 focusing on tool surface topography of CBN tool. Procedia Manuf. 2015, 1, 675-682. [CrossRef] 
29. Garcia-Gonzalez, J.C.; Moscoso-Kingsley, W.; Madhavan, V. Tool Rake Face Temperature Distribution when Machining Ti6Al4V and Inconel 718. Procedia Manuf. 2016, 5, 1369-1381. [CrossRef]

30. Abd Rahman, M.; Ali, M.Y.; Rosli, A.R.S.; Banu, A. Process Capability of High Speed Micro End-Milling of Inconel 718 with Minimum Quantity Lubrication. In Proceedings of the 3rd International Conference on Mechanical, Automotive and Aerospace Engineering 2016, Kuala Lumpur, Malaysia, 25-27 July 2016. [CrossRef]

31. Musfirah, A.; Ghani, J.; Haron, C.C. Tool wear and surface integrity of inconel 718 in dry and cryogenic coolant at high cutting speed. Wear 2017, 376, 125-133. [CrossRef]

32. Abd Rahman, M.; Ali, M.Y.; Khairuddin, A.S. Effects on Vibration and Surface Roughness in High Speed Micro End-Milling of Inconel 718 with Minimum Quantity Lubrication. In Proceedings of the 3rd International Conference on Mechanical Automotive and Aerospace Engineering 2016, Kuala Lumpur, Malaysia, 25-27 July 2016. [CrossRef]

33. Lu, X.; Zhang, H.; Jia, Z.; Feng, Y.; Liang, S.Y. Cutting parameters optimization for MRR under the constraints of surface roughness and cutter breakage in micro-milling process. J. Mech. Sci. Technol. 2018, 32, 3379-3388. [CrossRef]

34. Shi, Z.; Li, Y.; Liu, Z.; Qiao, Y. Determination of minimum uncut chip thickness during micro-end milling Inconel 718 with acoustic emission signals and FEM simulation. Int. J. Adv. Manuf. Technol. 2018, 98, 37-45. [CrossRef]

35. Lu, X.; Wang, H.; Jia, Z.; Feng, Y.; Liang, S.Y. Effects of cutting parameters on temperature and temperature prediction in micro-milling of Inconel 718. Int. J. Nanomanuf. 2018, 14, 377-386. [CrossRef]

36. Lu, X.; Wang, H.; Jia, Z.; Si, L.; Liang, S.Y. Effects of Tool Nose Corner Radius and Main Cutting-Edge Radius on Cutting Temperature in Micro-Milling Inconel 718 Process. In Proceedings of the 12th International Manufacturing Science and Engineering Conference, Los Angeles, CA, USA, 4-8 June 2017. [CrossRef]

37. Anand, K.; Mathew, J. Evaluation of size effect and improvement in surface characteristics using sunflower oil-based MQL for sustainable micro-endmilling of Inconel 718. J. Braz. Soc. Mech. Sci. Eng. 2020, 42, 1-13. [CrossRef]

38. Aslantas, K.; Alatrushi, L. Experimental Study on the Effect of Cutting Tool Geometry in Micro-Milling of Inconel 718. Arab. J. Sci. Eng. 2020, 1-16. [CrossRef]

39. De Oliveira, D.; Gomes, M.C.; da Silva, M.B. Influence of cutting fluid application frequency on the surface quality of micromilled slots on Inconel 718 alloy. Procedia Manuf. 2020, 48, 553-558. [CrossRef]

40. Lu, X.; Wang, F.; Xue, L.; Feng, Y.; Liang, S.Y. Investigation of material removal rate and surface roughness using multi-objective optimization for micro-milling of inconel 718. Ind. Lubr. Tribol. 2019, 71, 787-794. [CrossRef]

41. Kuram, E. Overhang length effect during micro-milling of Inconel 718 superalloy. J. Braz. Soc. Mech. Sci. Eng. 2019, $41,166$. [CrossRef]

42. Krishnan, N.A.; Mathew, J. Studies on wear behavior of AlTiN-coated WC tool and machined surface quality in micro endmilling of Inconel 718. Int. J. Adv. Manuf. Technol. 2020, 110, 291-307. [CrossRef]

43. Tadavani, S.A.; Razavi, R.S.; Vafaei, R. Pulsed laser-assisted machining of Inconel 718 superalloy. Opt. Laser Technol. 2016, 87, 72-78. [CrossRef]

44. D'addona, D.M.; Raykar, S.J.; Narke, M.M. High speed machining of Inconel 718: Tool wear and surface roughness analysis. Procedia CIRP 2017, 62, 269-274. [CrossRef]

45. Ucun, İ.; Aslantaş, K.; Gökçe, B.; Bedir, F. Effect of tool coating materials on surface roughness in micromachining of Inconel 718 super alloy. Eng. Manuf. 2014, 228, 1550-1562. [CrossRef]

46. Markopoulos, A.P.; Karkalos, N.E.; Mia, M.; Pimenov, D.Y.; Gupta, M.K.; Hegab, H.; Khanna, N.; Aizebeoje Balogun, V.; Sharma, S. Sustainability Assessment, Investigations, and Modelling of Slot Milling Characteristics in Eco-Benign Machining of Hardened Steel. Metals 2020, 10, 1650. [CrossRef]

47. Ucun, I.; Aslantas, K.; Bedir, F. An experimental investigation of the effect of coating material on tool wear in micro milling of Inconel 718 superalloy. Wear 2013, 300, 8-19. [CrossRef]

48. Lu, X.; Jia, Z.; Wang, H.; Si, L.; Wang, X. Surface roughness prediction model of micro-milling Inconel 718 with consideration of tool wear. Nanomanufacturing 2016, 12, 93-108. [CrossRef]

49. Aslantas, K.; Hopa, H.; Percin, M.; Ucun, I.; Cicek, A. Cutting performance of nano-crystalline diamond (NCD) coating in micro-milling of Ti6Al4V alloy. Precis. Eng. 2016, 45, 55-66. [CrossRef]

50. Özel, T.; Thepsonthi, T.; Ulutan, D.; Kaftanoğlu, B. Experiments and finite element simulations on micro-milling of Ti-6Al-4V alloy with uncoated and cBN coated micro-tools. CIRP Ann. 2011, 60, 85-88. [CrossRef]

51. Aramcharoen, A.; Mativenga, P.; Yang, S.; Cooke, K.; Teer, D. Evaluation and selection of hard coatings for micro milling of hardened tool steel. Int. J. Mach. Tools Manuf. 2008, 48, 1578-1584. [CrossRef]

52. De Oliveira, F.B.; Rodrigues, A.R.; Coelho, R.T.; de Souza, A.F. Size effect and minimum chip thickness in micromilling. Int. J. Mach. Tool. Manu. 2015, 89, 39-54. [CrossRef]

53. Altintas, Y. Manufacturing Automation: Metal Cutting Mechanics, Machine Tool Vibrations, and CNC Design; Cambridge University Press: Cambridge, UK, 2000.

54. Liu, X.; DeVor, R.E.; Kapoor, S.G.; Ehmann, K.F. The Mechanics of Machining at the Microscale: Assessment of the Current State of the Science. Trans. Asme 2004, 126, 666-678. [CrossRef]

55. Liu, X.; Jun, M.B.; DeVor, R.E.; Kapoor, S.G. Cutting Mechanisms and their Influence on Dynamic Forces, Vibrations and Stability in Micro-end Milling. In Proceedings of the ASME International Mechanical Engineering Congress and Exposition, Anaheim, CA, USA, 13-19 November 2004. 
56. Devillez, A.; Le Coz, G.; Dominiak, S.; Dudzinski, D. Dry machining of Inconel 718, workpiece surface integrity. J. Mater. Process. Technol. 2011, 211, 1590-1598. [CrossRef]

57. Imran, M.; Mativenga, P.T.; Gholinia, A.; Withers, P.J. Comparison of tool wear mechanisms and surface integrity for dry and wet micro-drilling of nickel-base superalloys. Int. J. Mach. Tools Manuf. 2014, 76, 49-60. [CrossRef]

58. Liu, Z.Y.; Li, C.; Fang, X.Y.; Guo, Y.B. Cumulative energy demand and environmental impact in sustainable machining of inconel superalloy. J. Clean. Prod. 2018, 181, 329-336. [CrossRef]

59. Lu, X.; Jia, Z.; Wang, H.; Hu, X.; Li, G.; Si, L. Measurement-based modelling of cutting forces in micro-milling of Inconel 718. Int. J. Nanomanuf. 2017, 13,1-11. [CrossRef]

60. Kovvuri, V.R. Experimental Study of Built-Up-Edge Formation in Micro Milling; Texas A\&M University: College Station, TX, USA, 2015.

61. Gandarias, E. Micromillng Technology: Global Review. Available online: https://www2.slideshare.net/endika55/micromillingtechnology-aglobal-review-71954776 (accessed on 25 October 2020).

62. Chae, J.; Park, S.S.; Freiheit, T. Investigation of micro-cutting operations. Int. J. Mach. Tools Manuf. 2006, 46, 313-333. [CrossRef]

63. Lee, K.; Dornfeld, D.A. Micro-burr formation and minimization through process control. Precis. Eng. 2005, 29, 246-252. [CrossRef]

64. Dornfeld, D.; Min, S.; Takeuchi, Y. Recent Advances in Mechanical Micromachining. CIRP Ann. 2006, 55, 745-768. [CrossRef]

65. Xiao, M.; Sato, K.; Karube, S.; Soutome, T. The effect of tool nose radius in ultrasonic vibration cutting of hard metal. Int. J. Mach. Tools Manuf. 2003, 43, 1375-1382. [CrossRef]

66. Liu, C.R.; Mittal, S. Single-step super finish hard machining: Feasibility and feasible cutting conditions. Robot. Comput. Integr. Manuf. 1996, 12, 15-27. [CrossRef]

67. Tansel, I.N.; Arkan, T.T.; Bao, W.Y.; Mahendrakar, N.; Shisler, B.; Smith, D.; McCool, M. Tool wear estimation in micro-machining.: Part I: Tool usage-cutting force relationship. Int. J. Mach. Tools Manuf. 2000, 40, 599-608. [CrossRef]

68. Weule, H.; Hüntrup, V.; Tritschler, H. Micro-cutting of steel to meet new requirements in miniaturization. CIRP Ann. 2001, 50, 61-64. [CrossRef]

69. Ucun, I.; Aslantas, K.; Bedir, F. The performance Of DLC-coated and uncoated ultra-fine carbide tools in micromilling of Inconel 718. Precis. Eng. 2015, 41, 135-144. [CrossRef]

70. Sahoo, P.; Patra, K.; Singh, V.K.; Gupta, M.K.; Song, Q.; Mia, M.; Pimenov, D.Y. Influences of TiAlN coating and limiting angles of flutes on prediction of cutting forces and dynamic stability in micro milling of die steel (P-20). J. Mater. Process. Technol. 2020, 278, 116500. [CrossRef]

71. Attanasio, A.; Gelfi, M.; Pola, A.; Ceretti, E.; Giardini, C. Influence of material microstructures in micromilling of Ti6Al4V alloy. Materials 2013, 6, 4268-4283. [CrossRef]

72. Sun, Z.; To, S. Effect of machining parameters and tool wear on surface uniformity in micro-milling. Micromachines 2018, 9, 268. [CrossRef]

73. Aurich, J.C.; Bohley, M.; Reichenbach, I.G.; Kirsch, B. Surface quality in micro milling: Influences of spindle and cutting parameters. CIRP Ann. 2017, 66, 101-104. [CrossRef]

74. Filippov, P.; Kaufeld, M.; Ebner, M.; Koch, U. Investigation of the Effect of End Mill-Geometry on Roughness and Surface Strain-Hardening of Aluminum Alloy AA6082. Materials 2020, 13, 3078. [CrossRef]

75. Zhou, M.; Chen, Y.; Zhang, G. Force Prediction and Cutting-Parameter Optimization in Micro-Milling Al7075-T6 Based on Response Surface Method. Micromachines 2020, 11, 766. [CrossRef]

76. Meijer, A.; Bergmann, J.A.; Krebs, E.; Biermann, D.; Wiederkehr, P. Analytical and Simulation-Based Prediction of Surface Roughness for Micromilling Hardened HSS. J. Manuf. Mater. Process. 2019, 3, 70. [CrossRef]

77. Bai, J.; Bai, Q.; Tong, Z. Multiscale analyses of surface failure mechanism of single-crystal silicon during micro-milling process. Materials 2017, 10, 1424. [CrossRef]

78. Koklu, U.; Basmaci, G. Evaluation of tool path strategy and cooling condition effects on the cutting force and surface quality in micromilling operations. Metals 2017, 7, 426. [CrossRef]

79. Moiz, M. The Influence of Grain Size on the Mechanical Properties of Inconel 718; Linköping University: Linköping, Sweden, 2013.

80. Kiswanto, G.; Zariatin, D.L.; Ko, T.J. The effect of spindle speed, feed-rate and machining time to the surface roughness and burr formation of Aluminum Alloy 1100 in micro-milling operation. J. Manuf. Process. 2014, 16, 435-450. [CrossRef]

81. Mian, A.J.; Driver, N.; Mativenga, P.T. Identification of factors that dominate size effect in micro machining. Int. J. Mach. Tools Manuf. 2011, 51, 383-394. [CrossRef]

82. Available online: https://www.chinacarbideinserts.com/product/Carbide-Twist-Drills.html (accessed on 25 October 2020).

83. Mian, A.J.; Driver, N.; Mativenga, P.T. Estimation of minimum chip thickness in micro-milling using acoustic emission. Proc. Inst. Mech. Eng. Part B J. Eng. Manuf. 2011, 225, 1535-1551. [CrossRef]

84. Gillespie, L.K. The formation and properties of machining burrs. J. Eng. Ind. 1973. [CrossRef]

85. Platt, T.; Meijer, A.; Biermann, D. Conduction-Based Thermally Assisted Micromilling Process for Cutting Difficult-to-Machine Materials. J. Manuf. Mater. Process. 2020, 4, 34. [CrossRef]

86. Jaffery, S.H.I.; Khan, M.; Ali, L.; Mativenga, P.T. Statistical analysis of process parameters in micromachining of Ti-6Al-4V alloy. J. Eng. Manuf. 2016, 230, 1017-1034. [CrossRef]

87. Hasçalık, A.; Çaydaş, U. Optimization of turning parameters for surface roughness and tool life based on the Taguchi method. Int. J. Adv. Manuf. Technol. 2008, 38, 896-903. [CrossRef] 